\title{
DO PRIMARY SCHOOL STUDENTS LIKE MATHEMATICS?
}

\author{
Anica Vragović \\ III. Primary School Varaždin, Croatia \\ Irena Klasnić \\ University of Zagreb, Croatia
}

\begin{abstract}
Importance of mathematics as a school subject is evident in a fact that it is a constituent part of core curriculum for basic education in all education systems in the world. First few years of education are of crucial importance to the formation of attitudes towards mathematics. Attitudes are important because they navigate our actions and by doing so, influence our reality and our future as well. Research on attitudes towards mathematics has considerably increased over the past few years, since the importance of mathematics is getting continuously more accentuated. In the context of schools and education, it is emphasized how positive attitude towards mathematics influences students' relationship with school-work, studying, confidence and behaviour. The aim of the study was to determine primary school students' attitudes towards mathematics. One hundred and seventy-one students from $3^{\text {rd }}$ to $8^{\text {th }}$ grade from III Primary School Varaždin, Croatia participated in the research. The data were analyzed with t-test and one-way ANOVA for independent samples. The research has shown that there is no statistically significant gender difference in attitudes towards mathematics; however, age difference was confirmed. It was also found that younger students in primary education had a more positive attitude towards mathematics than older students. Practical implications of acquired results could be in providing additional support to $5^{\text {th }}$ and $6^{\text {th }}$ grade students when the change from positive to negative attitude happens.
\end{abstract}

Keywords: age, attitude, gender, mathematics, primary education, students.

\section{Introduction}

Rapid development of science and technology is impossible without mathematics. Mathematical skills and competence are recognized as vital to personal and economic success (Lipnevich et al., 2011). Importance of mathematics as a school subject is evident in a fact that it is a constituent part of core curriculum for basic and also secondary education in all education systems in the world. Zhou et al. (2019) emphasize that primary education is an essential stage and has an important impact on students' learning attitudes throughout the coming school years.

Throughout history, attitudes have been defined in different ways. Krech and Crutchfield (1976) define attitude as permanent organization of perceptual, 
instinctive, emotional and adaptable processes tied to a certain aspect of human life. McLeod (1994) defines them as positive and negative emotional dispositions. Pennington (2001) describes attitude as a construct that is used as a guide to certain mental processes of a person. Aydin defines attitude as "a cognitive, affective and behavioral reaction the individual organizes toward himself/herself or any object, subject or fact around him/her based on information, feelings, and motivation" (2012, p. 334). Attitudes are not inherent; they can change as a result of an experience (Capuno et al., 2019).

Attitudes towards mathematics have been a topic of numerous research projects that have begun in the second half of 20th century. In the last 20 years, these research projects have become even more frequent. Today there is more and more talk about the development of STEM area (Science, Technology, Engineering and Mathematics) and with that, more interest in influences on evolution of mathematics.

\section{Review of the Literature}

Zan and Di Martino (2007) point out that an attitude towards mathematics is a construct which plays an important role in mathematics education. Students' attitudes play a vital role in the learning of mathematics (Kele \& Sharma, 2014), therefore attitude is a fundamental factor that cannot be ignored (Mazana, Montero, \& Casmir, 2019).

Early research about attitudes towards mathematics has shown that positive attitudes toward mathematics play a big role in mathematics education (Neale, 1969). The author classifies attitudes towards mathematics as liking or disliking, diligence or avoidance, good and bad attitudes towards mathematics and also classification by usefulness of mathematics. Students' attitudes towards mathematics are highly associated with their achievement in mathematics (Chagwiza et al., 2013; Tuncer \& Yilmaz, 2020). Research also shows that parents have a big role in forming of positive and negative attitudes towards mathematics (Arambašić \& Vlahović-Štetić, 2003; Mohr-Schroeder et al., 2017). Prior to formal education, mostly parents influence the formation of attitude towards mathematics, but in school, there are also other factors and influences. Teachers as role models can have a big impact on attitudes of students towards mathematics (Fržop, 2019). Oyedeji (2017) in his research confirms that parents, teachers and peers influence the formation of attitudes of students. Influence of peers on attitudes can also be positive or negative.

Research has so far shown that when children start going to school, they have a positive attitude towards mathematics; however, these attitudes change throughout their education and become more negative (Ma \& Kishor, 1997). Throughout education, negative attitude towards mathematics tends to become 
more and more negative, while at the same time the importance of mathematics in education and in life after education becomes more emphasized (Arambašić, Vlahović-Štetić, \& Severinac, 2005). Failing at grasping mathematical concepts very often generates the feeling of insecurity and students create a negative selfimage and feel incompetent (Sherman \& Christian, 1999).

Results of studies on gender differences mostly imply that mathematics is either a male-dominated area or that no gender differences were identified, but some studies show that females have a more positive attitude to mathematics than males (Kaldo \& Õun 2020, p. 597). Some authors explain that negative attitude towards mathematics in girls is formed in their upbringing through which an idea that mathematics is only for boys is imposed (Hyde, Fennema, Ryan, Frost, \& Hopp, 1990). After meta-analysis, Frost, Hyde and Fennema (1994) prove that gender differences in levels of success in mathematics are getting smaller. Despite that, many researchers have shown since that girls have a more negative attitude towards mathematics than boys do (Keller, 2001; Leedy, LaLonde, \& Runk, 2003; Arambašić et al., 2005; Else-Quest, Hyde, \& Linn, 2010; Markovits, \& Forgasz, 2017). Furthermore, most studies show that older students have a more negative attitude towards mathematics than younger ones (Hyde et al., 1990; Mata, Monteiro, \& Peixoto, 2012; Mazana, Montero, \& Casmir, 2019).

By looking into this issue, it was observed that in Croatia, the development of attitudes towards mathematics was monitored by gender, age, success and motivation and also that in the last 20 years, many studies have been conducted on this topic (Arambašić et al., 2005; Bušac, 2006; Pavlin-Bernardić, Ravić, \& Borović, 2012; Novak \& Brođanac, 2019). Concerning gender, most studies indicate that females generally have a more negative attitude towards mathematics than male examinees. With that, Vidić (2016) implies that boys have a more positive attitude towards mathematics than girls. It should be noted that not every research has shown the gender difference, for example in a study conducted by Cezner (2016), there was no difference in attitude towards mathematics between female and male students. Concerning age, younger students have a more positive attitude than older students (Pavlin-Bernardić et. al., 2010; Cezner, 2016; Vidić, 2016).

Primary education in Republic of Croatia lasts 8 years and is obligatory for all children from 6 to 15 years of age. During first 4 years of primary education students are taught by only one teacher (excluding foreign languages, religion and computer science). Generally, in grades 5 to 8 , every subject is taught by a different teacher (specialized for that subject).

The aim of the study was to determine primary school students' attitudes towards mathematics. 
In the study the following research questions are determined:

1) Is there a significant gender difference in the primary school students' attitudes towards mathematics?

2) Is there a significant grade level difference in the primary school students' attitudes towards mathematics?

\section{Methodology}

Following hypotheses were set:

H1: There is no significant gender difference in the primary school students' attitudes towards mathematics.

H2: There is no significant grade level difference in the primary school students' attitudes towards mathematics.

Sample of the study

Students (ages 9-15) from 3rd to 8th grade from III Primary School Varaždin, Croatia participated in this study. Research population were students of III Primary School Varaždin $(\mathrm{N}=292)$ and from that, non-representative probability sample $(\mathrm{N}=171)$ was defined. Students were split in three different age groups:

1. Group - $3^{\text {rd }}$ and $4^{\text {th }}$ grade students $(n=57)$

2. Group $-5^{\text {th }}$ and $6^{\text {th }}$ grade students $(n=58)$

3. Group $-7^{\text {th }}$ and $8^{\text {th }}$ grade students $(\mathrm{n}=56)$.

The probability sample consisted of 81 girls (47\%) and 90 boys (53\%).

Procedure of the study

Before conducting the research, an approval from the school principal was received. The participation was voluntary and anonymous. Also, a signed approval was received from every student's parent. The research was conducted in accordance with Ethical Standards for Research with Children. The data were collected through a survey carried out in April during school year 2019/20. The survey took place at the school during agreed classes and in the presence of teachers. The length of the survey was around 10-15 minutes and it was done using pen and paper.

\section{Instrument and Data Analysis}

Original instrument Attitudes Toward Mathematics Inventory (ATMI) consists of 49 item and the ATMI psychometric analysis revealed sound properties and therefore can be used by researchers and practitioners to measure students' attitudes toward mathematics (Tapia, 1996). An adapted version of the survey ATMI was used and it consists of 40 statements and measures 4 aspects: confidence, importance/usefulness, enjoyment and motivation. Students were asked to choose one of 5 offered levels of agreement on the Likert scale, where smaller values represented smaller levels of agreement with a statement. 
SOCIETY. INTEGRATION. EDUCATION

Proceedings of the International Scientific Conference. Volume II, May $28^{\text {th }}-29^{\text {th }}$, 2021. 624-634

The data were collected were analysed in SPSS 22 Statistics software. For comparative analysis, t-test and one-way ANOVA was used in order to examine the changes depending on gender and age variables.

\section{Results}

Statements that were not answered or had multiple different answers were omitted from the analysis. Before the analysis, statements from the questionnaire where the smallest possible number was the most positive answer were redefined, so that the smallest number also implied the most negative answer. Altogether there were 11 such questions, namely the questions $9,10,11,12,13,14,15,20$, 21, 25 and 28. After that, a composite variable which included all the other variables that measured students' attitude towards mathematics was defined. Afterwards, a descriptive statistic for individual statements from the questionnaire and for the composite variable "Attitudes of primary school students towards mathematics" was calculated. The data are presented in Table 1. Skewness is 0.685 which means that the data follow a normal distribution with a negative kurtosis of -0.263 .

Table 1 Descriptive Statistics of Students' Statements Attitudes Towards Mathematics

\begin{tabular}{|c|c|c|c|c|c|c|}
\hline & M & SD & $\begin{array}{c}\text { Skewne } \\
\text { ss }\end{array}$ & $\begin{array}{l}\text { S. St } \\
\text { Err }\end{array}$ & $\begin{array}{c}\text { Kurtosi } \\
\mathrm{s}\end{array}$ & $\begin{array}{l}\text { K.St } \\
\text { Err }\end{array}$ \\
\hline 1. Mathematics is a very worthwhile and necessary subject. & 4.67 & .680 & -2.569 & .186 & 7.864 & .370 \\
\hline 2. I want to develop my mathematical skills. & 4.33 & .992 & -1.668 & .187 & 2.439 & .371 \\
\hline $\begin{array}{l}\text { 3. I get a great deal of satisfaction out of solving a mathematics } \\
\text { problem. }\end{array}$ & 3.57 & 1.127 & -.843 & .187 & .117 & .371 \\
\hline $\begin{array}{l}\text { 4. Mathematics helps develop the mind and teaches a person to } \\
\text { think. }\end{array}$ & 4.59 & .832 & -2.549 & .186 & 7.061 & .370 \\
\hline 5. Mathematics is important in everyday life. & 4.62 & .761 & -2.666 & .186 & 8.412 & .370 \\
\hline $\begin{array}{l}\text { 6. Mathematics is one of the most important subjects for people } \\
\text { to study. }\end{array}$ & 4.36 & .907 & -1.689 & .186 & 3.072 & .370 \\
\hline $\begin{array}{l}\text { 7. High school math courses would be very helpful no matter } \\
\text { what I decide to study. }\end{array}$ & 4.64 & .760 & -2.851 & .187 & 9.379 & .373 \\
\hline 8. I can think of many ways that I use math outside of school. & 4.21 & 1.014 & -1.406 & .187 & 1.593 & .373 \\
\hline 9. Mathematics is one of my most dreaded subjects. & 3.44 & 1.511 & -.327 & .187 & -1.408 & .373 \\
\hline $\begin{array}{l}\text { 10. My mind goes blank and I am unable to think clearly when } \\
\text { working with mathematics. }\end{array}$ & 3.68 & 1.433 & -.602 & .187 & -1.039 & .371 \\
\hline 11. Studying mathematics makes me feel nervous. & 3.72 & 1.427 & -.631 & .187 & -1.105 & .371 \\
\hline 12. Mathematics makes me feel uncomfortable. & 3.95 & 1.389 & -.954 & .187 & -.573 & .371 \\
\hline 13. I am always under a terrible strain in a math class. & 3.79 & 1.440 & -.750 & .187 & -.939 & .373 \\
\hline $\begin{array}{l}\text { 14. When I hear the word mathematics, I have a feeling of } \\
\text { dislike. }\end{array}$ & 4.17 & 1.260 & -1.281 & .187 & .348 & .373 \\
\hline $\begin{array}{l}\text { 15. It makes me nervous to even think about having to do a } \\
\text { mathematics problem. }\end{array}$ & 3.91 & 1.394 & -.856 & .187 & -.727 & .371 \\
\hline 16. Mathematics does not scare me at all. & 3.53 & 1.508 & -.558 & .187 & -1.180 & .371 \\
\hline $\begin{array}{l}\text { 17. I have a lot of self-confidence when it comes to } \\
\text { mathematics. }\end{array}$ & 3.53 & 1.370 & -.690 & .188 & -.724 & .374 \\
\hline
\end{tabular}




\begin{tabular}{|c|c|c|c|c|c|c|}
\hline $\begin{array}{l}\text { 18. I am able to solve mathematics problems without too much } \\
\text { difficulty. }\end{array}$ & 3.62 & 1.222 & -.648 & 189 & -.539 & 376 \\
\hline 19. I expect to do fairly well in any math class I take. & 3.71 & 1.308 & -.792 & 188 & -.469 & 374 \\
\hline I am always confused in my mathematics class. & 3.82 & 1.270 & -.677 & 187 & -.756 & .373 \\
\hline en attemnting mathe & .46 & 435 & -.362 & 187 & -1.280 & 371 \\
\hline 22. I learn & 3.49 & .340 & -.478 & 187 & -.925 & .373 \\
\hline 23. I ar & 2.99 & 1.476 & -.092 & 187 & -1.391 & .373 \\
\hline 24. I hi & 3.70 & 1.238 & -.721 & .187 & -.439 & .371 \\
\hline 25. Mc & 4.02 & 1.270 & -1.022 & 187 & -.134 & .371 \\
\hline $26 . \mathrm{I}$ & 3.48 & 1.341 & -.510 & .187 & -.868 & .371 \\
\hline $\begin{array}{l}\text { 27. I would prefer to do an assignment in math than to write an } \\
\text { essay. }\end{array}$ & 3.76 & 1.602 & -.784 & 187 & -1.078 & .371 \\
\hline I would like to avoid using mathematics in college. & 3.34 & 1.484 & -.254 & 187 & -1.342 & .371 \\
\hline 29. Ir & 3.70 & 1.269 & -.678 & 188 & -.547 & .374 \\
\hline $30 . \mathrm{I}$ & 2.96 & 247 & -.213 & .187 & -971 & .373 \\
\hline 31. M & 3.92 & 1.172 & -.855 & .186 & -.248 & .370 \\
\hline $\begin{array}{l}\text { 32. I a } \\
\text { matheI }\end{array}$ & 3.50 & 1.158 & -.509 & 186 & -.547 & 370 \\
\hline alo as much mathomatics ac I an durin & 3.58 & 1.175 & -.577 & 186 & -.415 & 370 \\
\hline 34. T & 3.22 & 356 & -.273 & 186 & -1.088 & 370 \\
\hline $35 . \mathrm{It}$ & 4.14 & .113 & .207 & 186 & .692 & .370 \\
\hline lieve studying math helps me with problem solving in & 4.13 & 1.071 & -1.297 & 186 & 1.286 & .37 \\
\hline $\begin{array}{l}\text { 37. I am comfortable expressing my own ideas on how to look } \\
\text { for solutions to a difficult problem in math. }\end{array}$ & 3.60 & 1.233 & -.578 & 186 & -.485 & 370 \\
\hline 38. I am & 3.73 & 1.384 & -.778 & .186 & -.704 & 370 \\
\hline 39. A strong math background could help me in my professional & & 963 & -1.910 & 186 & 3.641 & \\
\hline . I believe I am good at solving math problems. & 3.62 & 1.264 & -.647 & 186 & -.581 & 370 \\
\hline titudes of students towards mathematics & 154.1 & 33.314 & -.685 & 199 & -.263 & 395 \\
\hline
\end{tabular}

Since further statistical analysis was on the composite variable Attitudes of students towards mathematics, the normality of the distribution was verified with the Kolmogorov-Smirnov test $(\mathrm{D}(148)=0.120 \mathrm{p}>0.01)$. Results show that the variable follows normal distribution and that parametric statistical tests were used for testing the hypotheses.

The first goal was to test if a statistically significant gender difference in attitudes towards mathematics exists. The difference was verified with the t-test for independent samples. It was shown that no statistically significant gender difference in attitudes towards mathematics exists $(t=0.989, \mathrm{df}=147, \mathrm{p}=0.324)$ and therefore, the first hypothesis is confirmed.

Furthermore, existence of statistically significant age/grade difference in attitudes towards mathematics was tested. The results shown in Table 2 indicate that students in 5th and 6th grade $(\mathrm{M}=148.292, \mathrm{SD}=35.106)$ and students in 7 th and 8th grade $(\mathrm{M}=141.300, \mathrm{SD}=33.597)$ have more negative attitude towards mathematics than students in grades 3 and $4(\mathrm{M}=172.137, \mathrm{SD}=22.189)$. 
SOCIETY. INTEGRATION. EDUCATION

Proceedings of the International Scientific Conference. Volume II, May $28^{\text {th }}-29^{\text {th }}$, 2021. 624-634

Table 2 Attitudes of Students Towards Mathematics by Age/Grade

\begin{tabular}{|c|c|c|c|c|c|c|c|c|}
\hline & \multirow[t]{2}{*}{$\mathrm{N}$} & \multirow[t]{2}{*}{ Mean } & \multirow[t]{2}{*}{ Std. Dev. } & \multirow[t]{2}{*}{$\begin{array}{l}\text { Std. } \\
\text { Error }\end{array}$} & \multicolumn{2}{|c|}{$\begin{array}{l}\text { 95\% Confidence } \\
\text { Interval }\end{array}$} & \multirow[t]{2}{*}{ Min. } & \multirow[t]{2}{*}{ Max. } \\
\hline & & & & & $\begin{array}{l}\text { Lower } \\
\text { Bound }\end{array}$ & $\begin{array}{l}\text { Upper } \\
\text { Bound }\end{array}$ & & \\
\hline $\begin{array}{l}\text { 3rd and 4th grade } \\
\text { students }\end{array}$ & 51 & 172.1373 & 22.18920 & 3.10711 & 165.8964 & 178.3781 & 103.00 & 198.00 \\
\hline $\begin{array}{l}\text { 5th and 6th grade } \\
\text { students }\end{array}$ & 48 & 148.2917 & 35.10589 & 5.06710 & 138.0980 & 158.4854 & 49.00 & 200.00 \\
\hline $\begin{array}{l}\text { 7th and 8th grade } \\
\text { students }\end{array}$ & 50 & 141.3000 & 33.59741 & 4.75139 & 131.7517 & 150.8483 & 62.00 & 196.00 \\
\hline Total & 149 & 154.1074 & 33.31426 & 2.72921 & 148.7141 & 159.5006 & 49.00 & 200.00 \\
\hline
\end{tabular}

In statistical analysis, a one-way ANOVA for independent samples was also calculated. It was shown that there is a statistically significant age/grade difference in attitudes towards mathematics (F2,146 = 13.982, $\mathrm{p}<0.01$ ). From this data, we can conclude that the second hypothesis can be rejected. In order to determine the difference, the Turkey post hoc test was used (Table 3). Among students in grades 5, 6, 7 and 8 no difference in attitudes towards mathematics was found $(p=0.05)$.

Table 3 Age/Grade Differences in Attitudes Towards Mathematics

\begin{tabular}{|l|l|l|l|l|l|l|}
\hline (I) Age/grade & (J) Age/grade & $\begin{array}{l}\text { Mean } \\
\text { difference } \\
\text { (I-J) }\end{array}$ & $\begin{array}{l}\text { Std. } \\
\text { Error }\end{array}$ & Sig. & $\begin{array}{l}\text { 95\% Confidence } \\
\text { Interval }\end{array}$ \\
\cline { 4 - 7 } & & $\begin{array}{l}\text { Lower } \\
\text { Bound }\end{array}$ & $\begin{array}{l}\text { Upper } \\
\text { Bound }\end{array}$ \\
\hline $\begin{array}{l}\text { 3rd and 4th grade } \\
\text { students }\end{array}$ & 5th and 6th grade students & 23.84559 & 6.17935 & .000 & 9.2138 & 38.4774 \\
\hline & 7th and 8th grade students & 30.83725 & 6.11535 & .000 & 16.3570 & 45.3175 \\
\hline $\begin{array}{l}\text { 5th and 6th grade } \\
\text { students }\end{array}$ & 3rd and 4th grade students & -23.84559 & 6.17935 & .000 & -38.4774 & -9.2138 \\
\hline & 7th and 8th grade students & 6.99167 & 6.20924 & .500 & -7.7109 & 21.6943 \\
\hline $\begin{array}{l}7 t h \text { and 8th grade } \\
\text { students }\end{array}$ & 3rd and 4th grade students & -30.83725 & 6.11535 & .000 & -45.3175 & - \\
\hline & 5th and 6th grade students & -6.99167 & 6.20924 & .500 & -21.6943 & 7.7109 \\
\hline
\end{tabular}

*.The mean difference is significant at the 0.05 level.

\section{Discussion}

With this research we wanted to test if there are gender or age differences in primary school students' attitudes towards mathematics.

According to acquired results, there is no statistically significant difference in attitudes towards mathematics between boys and girls, so first hypothesis was confirmed. Many studies have focused on gender differences in attitudes towards mathematics and according to some of them boys have a more positive attitude 
than girls (Keller, 2001; Leedy et. al., 2003; Arambašić et. al., 2005; Else-Quest, Hyde, \& Linn, 2010; Markovits, \& Forgasz, 2017). Results from other studies have shown that there is no statistically significant gender difference in attitudes (Nicolaidou \& Philippou, 2003). Possible explanation of our results is that the current primary education system provides adequate support for boys and girls, along with many mathematical activities that are offered and popularize mathematics (e.g. Math Night events, mathematics festivals, Eratosthenes Experiment, international mathematics competition Mathematical Kangaroo, centre for advanced/further mathematics). In all of these projects and activities, boys and girls are equally included and their attitudes towards mathematics are not much different.

Present study does not confirm the hypothesis about no existing age/grade level difference in the primary school students' attitudes towards mathematics. This finding is consistent with past research projects, older students tend to have a more negative attitude towards mathematics than younger students (Hyde et. al., 1990; Pavlin-Bernardić et al., 2012; Vidić, 2016). Our research has shown that students in $3^{\text {rd }}$ and $4^{\text {th }}$ have a more positive attitude towards mathematics than students in grades 5-8. Furthermore, we can see from the data that attitudes of students became considerably more negative in grades 5 and 6 . There could be several reasons for that change. Fifth grade students experience many changes in ways that classes are organised and taught. In grades 3 and 4 they still have a single-class-teacher who knows them well and there is a mutual understanding and connection. In grade 5, they get a different teacher for every subject and every teacher works and teaches in a different way. They also have four new subjects and consequently more classes which means they spend more time in school and have more things to learn. Apart from that, it seems that parents expect their children to be more independent and responsible at that age. The acquired result could also be a consequence of peer pressure, students of that age (12-13) are often characterized by dislike for teachers' and parental authority and for schoolwork in general.

This research was conducted on a probability sample of students in III. Primary School Varaždin and because of that, we cannot generalize our results to all primary schools in Croatia, but it would be useful to do the same study in other primary schools in Varaždin and Varaždin County, so that a comparative analysis could be done.

Practical implications of acquired results could be in providing additional support to 5th and 6th grade students when the change from positive to negative attitude happens. 
SOCIETY. INTEGRATION. EDUCATION

Proceedings of the International Scientific Conference. Volume II, May $28^{\text {th }}-29^{\text {th }}$, 2021. 624-634

\section{Conclusions}

Attitudes are important because they navigate our actions and in doing so, influence our reality and also our future. Positive or negative attitude towards mathematics is probably going to determine the future education path, career and life of our students. Even though students realise the potential and value of mathematics and rate it very high in terms of importance, it is evident that there is a certain anxiety towards it and a low level of satisfaction students get from it.

This research has not confirmed any gender differences in attitudes towards mathematics, while the age difference was confirmed. Younger students tend to have a more positive attitude towards mathematics than older students. That result should be understood as a "pointer" so that students' attitudes could be guided to a more positive direction. Mathematics classes should build bridges between mathematics as a subject and science, not break them. According to our results, it seems that the most negative change happens around the age of 12 and therefore, we should concentrate our efforts on that age group.

\section{References}

Arambašić, L., \& Vlahović-Štetić, V. (2003). Relation between children's math grades and attitudes and parents' attitudes toward mathematics. In L.Mason, S.Andreuzza, B.Arfe, \& L.Del Favero (Eds.), 10th European Conference for Research on Learning and Instruction - Abstracts. Padova, CLEUP.

Arambašić, L., Vlahović-Štetić, V., \& Severinac, A. (2005). Je li matematika bauk? Stavovi, uvjerenja i strah od matematike kod gimnazijalaca. Društvena istraživanja: časopis za opća društvena pitanja, 14(6 (80)), 1081-1102.

Aydin, I.E. (2012). Attitudes toward online communications in open and distance learning. Turkish Online Journal of Distance Education, 13(4), 333-346.

Bušac, M. (2006). Stavovi $i$ uvjerenja prema matematici učenika viših razreda osnovne škole. (Doctoral dissertation). Zagreb: Filozofski fakultet Sveučilišta u Zagrebu.

Capuno, R., Necesario, R., Etcuban, J.O., Espina, R., Padillo, G., \& Manguilimotan, R. (2019). Attitudes, Study Habits, and Academic Performance of Junior High School Students in Mathematics. International Electronic Journal of Mathematics Education, 14(3), 547-561.

Cezner, A. (2016). Učenje matematike bez straha. (Doctoral dissertation). Split: Faculty of Humanities and Social Sciences, University of Split.

Else-Quest, N.M., Hyde, J.S., \& Linn, M.C. (2010). Cross-national patterns of gender differences in mathematics achievement, attitudes, \& affect: A meta-analysis. Psychological Bulletin, 136, 103-127.

Frost, L.A., Hyde, J.S., \& Fennema, E. (1994). Gender, mathematics performance, and mathematics-related attitudes and affect: A meta-analytic synthesis. International Journal of Educational Research, 21(4), 373-385.

Fržop, M. (2019). Procjep između nastave matematike u nižim i višim razredima osnovne škole. (Doctoral dissertation). Zadar: Department of Teachers and Preschool Teachers Education, University of Zadar. 
Hyde, J.S., Fennema, E., Ryan, M., Frost, L.A., \& Hopp, C. (1990). Gender comparisons of mathematics attitudes and affect: A meta-analysis. Psychology of women quarterly, 14(3), 299-324.

Kaldo, I., \& Õun, K. (2020). Gender Differences Favouring Females in Learning Strategies in Mathematics. Problems of Education in the 21st Century, 78(4), 595-611.

Kele, A., \& Sharma, S. (2014). Students' beliefs about learning mathematics: Some findings from the Solomon Islands. Teachers and Curriculum, 14, 33-44.

Keller, C. (2001). Effect of teachers' stereotyping on students' stereotyping of mathematics as a male domain. The Journal of Social Psychology, 141(2), 165-173.

Krech, D., \& Crutchfield, R. (1976). Elementi psihologije. Beograd: Naučna knjiga.

Leedy, M.G., LaLonde, D., \& Runk, K. (2003). Gender equity in mathematics: Beliefs of students, parents, and teachers. School Science and Mathematics, 103(6), 285-292.

Ma, X., \& Kishor, N. (1997). Assessing the relationship between attitude toward mathematics and achievement in mathematics: A meta-analysis. Journal for research in mathematics education, 28(1), 26-47.

Markovitz, Z., \& Forgasz, H. (2017). "Mathematics is like a lion”: Elementary students' beliefs about mathematics. Educational Studies in Mathematics, 96(1), 49-64.

Mata, M. de L., Monteiro, V., \& Peixoto, F. (2012). Attitudes towards Mathematics: Effects of Individual, Motivational, and Social Support Factors. Child Development Research, 2012, 1-10.

Mazana, M.Y., Montero, C.S., \& Casmir, R.O. (2019). Investigating Students’ Attitude towards Learning Mathematics. International Electronic Journal of Mathematics Education, 14(1), 207-231.

McLeod, D.B. (1994). Research on Affect and Mathematics Learning in the JRME: 1970 to the Present. Journal for Research in Mathematics Education, 25(6), 637-647.

Mohr-Schroeder, M.J., Jackson, C., Cavalcanti, M., Jong, C., Craig Schroeder, D., \& Speler, L.G. (2017). Parents' Attitudes Toward Mathematics and the Influence on Their Students' Attitudes toward Mathematics: A Quantitative Study. School Science and Mathematics, 117(5), 214-222.

Neale, D.C. (1969). The role of attitudes in learning mathematics. The Arithmetic Teacher, 16(8), 631-640.

Nicolaidou, M., \& Philippou, G. (2003). Attitudes towards mathematics, self-efficacy and achievement in problem solving. European Research in Mathematics Education, 3, 1-10.

Novak, J., \& Brođanac, P. (2019). Što je bolji prediktor uspjeha iz matematike i fizike-stavovi prema matematici ili kapacitet radnog pamćenja. Život i škola: časopis za teoriju i praksu odgoja i obrazovanja, 65(1-2), 31-44.

Oyedeji, S. O. (2017). The Effects of Students' Motivational Factors on Their Attitudes toward Mathematics. International Journal of Evaluation and Research in Education, 6(4), 277-287.

Pavlin-Bernardić, N., Ravić, S., \& Borović, K. (2012). Povezanost učeničkih stavova i uvjerenja prema matematici i kognitivnih sposobnosti $\mathrm{s}$ ocjenama iz matematike. Napredak: časopis za pedagogijsku teoriju i praksu, 153(3-4), 315-326.

Pennington, D. C. (2001). Osnove socijalne psihologije. Jastrebarsko: Naklada Slap.

Sherman, H. J., \& Christian, M. (1999). Mathematics attitudes and global self-concept: An investigation of the relationship. College Student Journal, 33(1), 95-101.

Tuncer, M., \& Yilmaz, Ö. (2020). Relations Attitude Towards Mathematics Lessons: Anxiety and Academic Success. REDIMAT - Journal of Research in Mathematics Education, 9(2), 173-195. 
SOCIETY. INTEGRATION. EDUCATION

Proceedings of the International Scientific Conference. Volume II, May $28^{\text {th }}-29^{\text {th }}, 2021.624-634$

Zan, R., \& Di Martino, P. (2007). Attitude toward mathematics: Overcoming the positive/negative dichotomy. The Montana Mathematics Enthusiast, 3, 157-168.

Zhou, S.-N., Zeng, H., Xu, S.-R., Chen, L.-C., Xiao, H. (2019). Exploring changes in primary students' attitudes towards science, technology, engineering and mathematics (STEM) across genders and grade levels. Journal of Baltic Science Education, 18(3), 466-480. 